\title{
Developing A Thinking Strategy On Understanding Numeracy Among Students Of School In Hospital (SDH)
}

\author{
${ }^{1}$ Siti Rahaimah binti Ali, ${ }^{2}$ Anida binti Sarudin, ${ }^{3}$ Zuria Farhana binti Muhamad \\ 1,2,3Universiti Pendidikan Sultan Idris, Malaysia \\ siti.rahaimah@fpm.upsi.edu.my
}

Article History: Received: 11 January 2021; Accepted: 27 February 2021; Published online: 5 April 2021

\begin{abstract}
This study aims to identify the level of numeracy comprehension, develop numeracy comprehension thinking strategy at the level of numeracy comprehension, evaluate and validate the numeracy comprehension strategy of students of school in hospital according to the level of numeracy comprehension. This research method uses quasi experimental. The results of this research are expected to provide a model of thinking strategies based on numerical comprehension models while helping students undergo treatment. Through this research grant is also able to identify the level of numeracy understanding for students in the School of Hospital (SDH) for marztghhthematics subjects. This study is a prelude to applying PRGS to develop an innovation that is an android game by applying a mathematical thinking model that is an innovation strategy in assessment to determine the level of numeracy comprehension in order to produce students with High Order Thinking Skills (HOTS). Participant, hospital, predict outcome, need for the future. In order to achieve the aspirations of the Malaysian Education Plan 2013-2025, the development of a numerical understanding level thinking strategy is essential. Education in Malaysia needs to be delivered to all students whether they are in normal condition or in hospital treatment. Currently, there are only 15 hospitals in the hospital. The teachers in these schools are very limited and they teach in all subjects that are syllabus similar to those of the regular school. Therefore, for mathematics subjects there is a need for a model of learning and teaching that is all-inclusive and assessmentbased to help teachers and pupils enjoy learning and at the same time thinking strategies can be developed in the minds of students. Therefore, a method of developing thinking strategies is essential in numeracy as well as focusing on the 21 st century skills. Therefore, a thinking strategy needs to be developed to enable teachers to determine their students' level of understanding of numeracy.
\end{abstract}

Keywords: Numeracy Understanding Model, mobile learning (M-Learning), e-Assessment, mobile app

\section{Introduction}

In line with UNESCO's missions to provide education for all and sustainable education, Malaysia has created another dimension in national education by establishing an Sekolah Dalam Hospital (SDH), aimed to ensure that regardless of circumstances, educational services are accessible to all students whom receiving treatment in hospital ward. Establishment of SDH is a collaboration between the Ministry of Education Malaysia (MOE), Ministry of Health Malaysia (MOH) and Non-Governmental Organizations (NGOs) to provide education to students in hospitals who are ready to learn.

According to the "Education for All (EFA)" principle outlined by The United Nations Educational, Scientific and Cultural Organization (UNESCO), every child, adolescent and adult should be provided with basic education. One of the six (6) internationally recognized educational goals are, "Ensuring that by 2015 all children, particularly girls, children in difficult circumstances and those belonging to ethnic minorities, have access to, and complete, free and compulsory primary education of good quality ".Learning session at school in hospital is a fun and flexible learning approach in a conducive environment. It is indirectly a therapy that can help the process of recovery of the health problem that the student is suffering from. Thus, in order to encourage school in hospital teachers to implement more creative and innovative teaching and learning (PdPc), a more effective numerical reasoning strategy should be produced, at the same time this will allow students to know their respective levels of numeracy. This thinking strategy emphasizes multi-grade learning and teacher-led instruction as a facilitator. Learning is oriented towards self-directed learning, self-accessed learning, self-paced learning and self-assessed learning.In line with this, to achieve the aspirations of the Malaysian Education Plan 2013-2025 through the first shift by providing equal access to international quality education also supported UNESCO's goals. Malaysia has taken various initiatives to expand access and equity of education as well as improve the quality of education, in line with the Minister of Educationspeech in UNESCO Malaysia Day 2013; "Through the Malaysian Education Development Plan (PPPM) 2013-2025, I will ensure that quality education is provided to all students regardless of grade and background. "

Therefore, a method of learning and evaluation especially in enhancing the elements of "thinking strategy" is essential in numeracy as well as focusing on 21 st century skills. Thus, a thinking strategy based on the Numerical Understanding Model (MPKN) developed by Siti Rahaimah (2014) need to be applied so that teachers can determine their students' understanding of numeracy and have fun learningsession. The objectives 
of this study were to identify the level of numeracy comprehension of SDH students, develop the numeracy comprehension strategy of the SDH students according to the numerical comprehension level and evaluate and validate the thinking strategies of the SDH students' numeracy regardless of the situation and place including students receiving treatment in hospital ward. This research method uses experimental quasi where there is a pre and post to obtain data on the level of numeracy understanding of SDH students and assessment strategies.

This study involves two main phases which is identifying the level of numeracy comprehension of SDH students (intensive literature review, questionnaires and interviews with coordinator / specialist teachers / hospitalists) and developing strategies for thinking numeracy understanding of SDH student numeracy based on numerical comprehension level ( characterization of numeracy comprehension level by MPKN) and assess and validate numeracy comprehension strategy of SDH students by conducting workshops with SDH teachers.

The results of this research are expected to propose a strategy of numeracy comprehension thinking among SDH students in order to produce students with high order thinking skills (HOTS), soft skills and self-directed learning and to identify the level of numeracy comprehension for students in SDH for numeracy. This study is a prelude to applying PRGS, which is to build a numerical understanding strategy model for students receiving treatment in SDH throughout Malaysia.

\section{Problem Statement}

SDH is the only school designed to help children who are receiving treatment to undergo teaching and learning so that they are not to be distracted by learning like other children. In Malaysia there are 15 SDHs to incorporate learning into children during treatment. In SDH, students learn according to a predefined schedule and use the same curriculum as the mainstream which make it difficult for teachers to identify the understanding level of SDH students especially in mathematics. Where, there is no single thinking strategy used to determine the level of numeracy comprehension for SDH students. Therefore, in order to facilitate the assessment of SDH teachers in determining the level of numeracy comprehension of SDH students, an understanding thinking strategy is necessary for these students to think and learn in exciting environment. Therefore, we can produce a generation with high problem solving skills even when these students are in treatment.

The level of thinking strategy for numeracy can be seen in many positive aspects of student's personalities. However, the level of understanding of numeracy is a very complex process. Goldin (1992: 275) explains, “.... Problem solving involves a highly complex aggregate of internal psychological processes, which may include verbal and syntactic processing; representation; the use of a variety of complex heuristics; conceptual understanding; a variety of affective responses; metacognitive processes; belief systems about mathematics...". Some mathematical problem solving models have been proposed by mathematics education researchers such as Polya (1957), Davis (1984), Schoenfeld (1985), Krulik and Rudnick (1996). The KBSM (PPK, 2011) and KSSM (PPK, 2012) certainly emphasize the above skills. Since KBSM was implimented, teachers have been encouraged to use Polya's problem solving model (1974). However,a lot of research conducted until now showing that student still have a low performance ofproblem solving and reasoning skills (Siti Rahaimah, 2016; TIMSS, 1999-2011; PISA 2009; Nor'ain et al. 2011a, 2011b, Zarimah, 2011, Parmjit \& Lau, 2006). For example, analysis of the Trends in International Mathematics and Science Study (TIMSS) report (2011), showed that Malaysian students' achievement in mathematics education experienced a sharp decline between 1999 and 2011. Specifically, three dimensions showed that student achievement was not satisfactory which is knowledge (35\%) questions, application (40\% questions) and reasoning (25\% questions). Details of student performance also indicate that only $2 \%$ to $10 \%$ of students reach a high level where at this point students are not able to handle information, make conclusions and generalizations and solve complex problems. This provides an indication that our students only understand the basic concepts but are generally unable to apply that knowledge (MOE, 2012).

Therefore, in order to achieveMalaysian Education Development Plan (PPPM) 2013-2025 aspiration, Malaysian education system needs to provide greater performance improvement based on international education benchmarks in line with international standards (PPPM, 2012). These improvements include standards for the field of Mathematics and focuses more on 21st century skills such as problem solving and reasoning skills. Therefore, improvements need to be made to ensure long-lasting high performance of education system in our country in developing the element of purity and competence that students need to succeed and thrive in an increasingly globalized world. Therefore, this research is designed a 'thinking strategy' based on Numerical Comprehension Thinking Strategies in solving mathematical problem for students receiving treatment in SDH throughout Malaysia. Thinking strategy is divided into 4 stages which is de-coding,meaning-making, using and analysing. Each of these stages has specific characteristics that determine students understanding of numeracy. In hope that this project will be able to produce students with higher order thinking skill while receiving hospital treatment. 


\section{Literature Review}

The numerical understanding model consists of four stages namely de-coding, knowledge-making, applicationand analyzing (Luke and Freebody, 2009) adapted by Siti Rahaimah (2014). Just because of numerical understanding, teaching and learning processes are complex (Ball, 2002; Kilpatrics, Swafford and Findell, 2001), this project focuses only on developing numerical comprehension thinking strategies based on critical numerical research models (Jane Watson, 2008). This numeracy understanding thinking strategy emphasizes several key elements in developing numeracy understanding among SDH students, including providing students with an opportunity to understand numeracy concepts and understand context before understanding more complex thinking. Second, it provides opportunities for exploration with others such as pairs, groups or whole-class discussions where different views can be gathered. Third, give students the opportunity to create something that applies from new knowledge that they gain, especially explaining their results to peers and in preparation for answering questions in exam.

According to Ornstein and Hunkins (2004), learning cannot be separated from children's daily life, but learning must be based on children's needs and interests. This is in line with the implementation of the School In Hospital program which gives children the opportunity to continue gaining knowledge despite facing their health problems. The teaching and learning process of SDH has been modified to fit the child's circumstances and to meet their needs as students.

Therefore, through this numerical understanding thinking strategy student are able to draw on ideas and relate to each other to solve the problems given (Christine Ludwing, 2004). This numerical understanding thinking strategy can also serve as a checklist for teachers and students to see the insights that individuals have implemented, to explore types of thinking skills, and to enable students to analyze the given questions. This numerical understanding thinking strategy makes it easier for students to express their thinking and adapt it to everyday life (Steven Figg, 2009). A checklist for both students and teachers with questions about what thinking skills do we have; do we need to explore other types of thinking skills, what happens if we analyze the question. This strategy makes it easy for students to use it so that everything that comes to mind can be written in stages like this model of numerical comprehension. Through this model, each discussion is not just a re-coding, but through this model each idea has its own level and each idea can be categorized according to the stages in the numerical comprehension model.

Through this level of numeracy understanding thinking strategies, students can think of various strategies used in the given stages. Students need to get used to this stage and the use of it maybe takes a long time at the beginningfor students to adapt but soon this will become a habit. Students can also use this numerical model in other subjects. This is supported by the Harvard Zero Project (2010), proposing to develop student understanding during and after activities which students can be asked to reflect their thinking skills with questions such as; what numerical ideas would you like to know more about the outcome of this investigation.

Difficulties in identifying the steps and onwards for developing student understanding (Watson, Callingham \& Donne, 2008a). Numeracy involves different ways of solving problems. There is not just one way to get the right answer. Students find it useful to discuss the types of strategies they use in their real life. Implementing this strategy have rising student's confidence and this was convinced that there was only one way to perform the process in numeracy (Halliday and Marr 1995, p. 75).

For each numerical question, the solution according to the numerical model needs to follow the procedure and the stages of practical knowledge. This makes it easier for students to find answers to any questions. The model's framework also coincides with learning in a constructivist approach of learning, whereby new knowledge relates to what they already know, builds their own understanding, and creates new meanings. This approach can help students to recognize numerical features in daily life ( $\mathrm{Gal} 2002)$.

Based on this numerical understanding thinking strategy framework, students can develop their own thinking strategies according the situations, this in return will help students develop their intelligence so that they can makedecisions that are social, environmental, and daily life. The strategy itself can act as a transformative tool for teachers either than teaching in traditionalmethods. However, this strategy needs to be practiced in teaching and learning so that students have the ability to practice learning numeracy.

This strategy can also help students to build and understand numerical concepts. Students create their own ideas and knowledge to think of new ideas. Through this numerical strategy framework, it is possible to know what students know such as early exploration, brainstorming, challenging questions, quizzes and questions that encourage studentsto think. Teachers play an important role in the classroom to investigate students' early understanding by exposing to activities that can help them focus on what are we going to learn and knowledge that they already know. This can raise some questions, give them some case studies to make them think, explore some different phenomena and asking them to contribute ideas.

This level of numeracy understanding strategy framework, in turn, can generate deeper numerical ideas based on topics in mathematics. Students are given a few examples of self-help questions and help students familiarize themselves with de-coding and meaning-making, then to the next stages of application (using), and analysis (Luke and Freebody, 2009). Using this model can also help students to apply their own understanding creatively to solve questions. 
Numerical comprehension strategy thinking strategies are adapted from the Numerical Understanding Level Model which includes the following stages of numeracy comprehension:

Stage 1: De-coding

In this stage, de-codingis used to ensure that students state the mathematical terminology used, for example students can state the basis of calculation which are plus, subtract, multiply and divide and students also beable to state the terminology in terms of numbers, measurements, fractions, geometric shapes etc. At this level, students can also be listingthe terms, ideas, languages and all mathematical information and adapt them in the form of concept maps. At this stage student learn vocabulary and for all numerical information. For example, geometry students can recognize a given shape, draw a shape and recreate it to form an object (Noraini Idris, 2005) which all information and mathematical terms will be collected then categorize them into mathematical concepts (Rivalland, 2000).

After identifying mathematical concepts, at this stage student are able to recognize diagrams by looking at the whole entity of objects without knowing the features.For example, geometric concepts are viewed as whole entities rather than their components or properties. Geometric shapes are known by their overall shape, which is the physical shape of the diagram and not the component or nature of the shape. Through this process students will contribute ideas to various perspectives on numeracy. This can be done individually, or involves a class. Make sure students are ready to present ideas so that new ideas can be gained from the students. This will encourage students to rethink what they have learned in order to come up with new ideas to solve a numeracy problem. After that, the students were asked to express themselves in the comments section. This will create ideas that are relevant to the students' self-esteem based on their understanding.

At this level, students will be able to identify mathematical concepts, for example in numbers, basis of calculation, measurement, shape and space as well as statistics. At this stage student can also state the basic processes and procedures in mathematics. For example, students can state operationsinvolved in solving a given question. Through this stage, students are able to write their initial thoughts on a given process and procedure for a given questions using fraction, addition etc. At this stage, students' understanding of questions and procedures will enable them to come up with new ideas about numeracy. This will provide continuity to existing knowledge after students have passed through this stage. This process helps the student develop confidence to solve a given question. It also encourages them to rethink what they have learned in order to come up with new ideas and to explain how to get a basic fact before solving a problem.

At this level, students are able to illustrate and draw basic mathematical ideas. Students at this level are able to illustrate some of the key ideas of mathematics, as drawing is a pure knowledge of a person who is triggered by past experience built on advanced knowledge. It is the impression that is generated immediately (Staffe, 2009). This situation reflects the understanding of the numerical concepts of students as a result of what they learn and what they represent. Students also at this stage can represent their understanding of numerical concepts in the form of diagrams. These representations are made repeatedly on the basis of their experience. For example, students redefine knowledge of fractions, measurements and so on by drawing, drawing materials and so on.

\section{Stage 2: Meaning-making}

Students at this level are able to explain how to get basic mathematical facts, for example students can explain a question that involves the basis of calculations by explaining and understanding what operations are used. In addition, students will be able to explain the processes and procedures used to solve a question and be able to match mathematical concepts after reading the given questions. Students are also able to generate their own idea during the brainstorming session; this will create relevant ideas based on their understanding. Students also learned how to get basic mathematical facts and how mathematical concepts could be understood based on the content of the given questions. At this level, students can also explain their initial thoughts, ideas and questions to understand a particular topic better. Thus, they will be able to come up with new ideas and have continuity with previous thoughts on a topic once they have gone through the process. At this stage, students are also exposed on how to obtain different data and can be more clearly or more formally presented in order to be interpreted accurately in an orderly way. In other words, students can decide which operations to use to get answers (Anstey, 2003).

At this level,students are encouragingto think about something, such as a problem, question or topic, and then voice their views. This will encourage the continuation of conceptual understanding through active arguments and explanations as students hear and share ideas, as well as encourage students to understand various perspectives. Knowledge acquisition is used when students solve numeracy problems, teachers can ask students to take time to think about a question or issue and share their thoughts with classmates. Acquiring knowledge can also be done in small groups, then formulating their ideas for the whole class.

As a result of this knowledge acquisition, students take turns presenting their own opinions, listening carefully and asking each other questions. One wayto make sure that students listen to each other by tellingthem to explain to their peers what they understand, rather than to express their thoughts. Students will be able to anticipate how 
different data can be formulated more clearly and systematically. In other words, students can determine what operation will be used to get the answer. At this stage, students can match their thoughts to a problem in a question or topic and then have their ownexplanation. This will encourage their understanding through arguments, sharing ideas and at the same time encouraging students to understand various perspectives in solving a problem in numeracy. Students will be able to match mathematical concepts as a result of knowledge acquisition.

At this stage student can expect how to obtain different data. When a question is given, student will be able to expect some data to be derived from the question given. Thus, students will match their thoughts to the questions posed by the topics they have followed. Here they will express their views and present ideas through a variety of perspectives in number, calculation, measurement, shape and space as well as statistics. Students will expect the operation to be used to solve a given question.

\section{Stage 3: Application (using)}

At this stage, students are able to complete the data obtained by making predictions, developing models and mapping concepts to solve the questions presented and considering the information or data to apply to the solution (Martin, 2008). Students can also relate the concept of numeracy to everyday life, for example the transition of time concept can be applied to the daily life of the students. Students at this level will be able to choose the appropriate procedure and use it correctly in solving a question. The students' ability to solve related questions is an indication of whether a student has mastered a concept or procedure in numeracy. At this application level student will be able to solve a question when they really understand the concept or procedure in numerical problems. Students are able to relate the concept of numeracy to their daily lives which allowing them to choose the appropriate procedure and use it appropriately in solving a question. Students' ability to solve questions is an indication of whether students can master a concept or understanding in numeracy. Students can also determine the appropriateness of a principle to be used in solving new problems by providing a logical basis for the decision they make.

At this stage student are wise in determining appropriate procedures for solving numerical comprehension and students be able to obtain important facts or concepts of numeracy that are useful in solving the questions given. From the question or text given portray students understanding ability and students apply different numerical concepts to the questions given. As a result, students will apply the data by making predictions, developing models, researching, visualizing scenarios, or creating concept maps to solve the given questions and consider the information or data to apply to the given problem solving.

Students at this level can provide reasons or justifications for decisions made to solve new problems using the principles they follow. Students are able determine the appropriateness of a concept and principle to be used in solving a new problem by providing a rational and factual basis for a numerical concept. Students will also reiterate an old problem to determine principles that can be used to solve a new problem and apply different mathematical concepts to solve a given problem. Here students are wise to consider the information or data to apply to any solution to a given problem. (Luke \& Freebody, 2009).

Study shows that students cannot apply a problem first without experiencing the process of interpreting code and acquiring knowledge (Carpenter, Moser \& Bebout, 2008). For example, students cannot solve a problem spontaneously without knowing the basic operations. This is because they often expect new problems as a result of changes in their calculation (Ryan, 2009). The findings of this research show that students cannot translate numerical information properly. Therefore, students need to be trained to form a representation first before going through the application stage.

\section{Stage 4: Analyzing}

At this level, students will be able to demonstrate mathematical concepts, procedures used and be able to prove mathematical facts to support the answers provided. Students are able to determine the relationship between the evidence and the answers given, which means students can prove that each answer given is using the appropriate mathematical concepts. This includes making reasonable assumptions as well as obtaining different views from various mathematical concepts. The purpose of the analysis was to determine the thinking skills among the students, which allowed them to develop good questions in order to spark their thinking and investigate the topic. They can also describe the procedures used based on the facts and evidence provided. This will help students brainstorm various types of questions on the topic and understand the reason given. The purpose of asking deep and interesting questions is to get at least the complexity and depth of a topic while also providing concrete arguments.

Therefore, through various thoughts and arguments on a given topic or question students will find various information discussed on the topic and the answers. This will produce students who are well versed in the mathematical concepts used. At this stage student are able to distinguish some reasonable assumptions and encourage students to take responsibility for any evidence or argument presented. This will increase their motivation to investigate when answering a given question. Here students can learn a new concept or topic, this will help students to get the latest information on the topic of interest. This level of analysis can also be used 
during the learning session and as a way to stimulate student curiosity. Analysis can also be used when approaching the end of studying a topic, as a way for students to demonstrate how the knowledge they have gained about the topic helps them to ask more interesting questions and to argue.

At this stage, students must be bold in deciding on a particular question or topic of learning. They must be confident to the answers given when solving aquestion, because they need to make sure that all the facts and concepts used in the analysis of a question are precise and accurate. They also be able to prove the concepts or facts used in the solution to support the answers provided. Students are also able to determine the relationship between logical evidence, able to explain and argue about a fact or concept used to fit the answer given. Students at this stage have made the decision based on convincing evidence of a decision made. Students also believe in the mathematical or terminological concepts used and ensure that all facts and concepts are used for analysing (Stewart, 2003).

\section{Research Objective}

This study aims to create and compare the usability of entertainment-based teaching and learning modules for the level of numeracy comprehension for children in hospitals. To fulfill this purpose, the objectives of the study to be achieved through this study is:

- Develop entertainment-based teaching and learning modules for numeracy comprehension level for InHospital School student.

\section{Methodology}

The module development process involves the construction of a draft module made based on the findings of needs analysis, theory, literature review and curriculum review. Modules generated. Reviewed by four field experts using expert review forms for improvement purposes. Expert recommendations are formulated in the table to get an idea of which parts need to be improved. Tessmer (2016) suggests that qualitative data obtained from experts be organized and scheduled to get an overview of specific areas that need to be improved. The purified module was then given to 20 evaluators, namely the same four experts and 16 SDH KPM teachers to evaluate and confirm the accuracy of the module content in terms of delivery, content and delivery.

Evaluation of the validity of the module content was made using a module content validity questionnaire that required the evaluator to provide answers in the form of a five-point Likert scale, namely: (1) strongly disagree. (2) Disagree. (3) Uncertain. (4) Agree, (5) Strongly agree. Data were analyzed using the module content validity counting method proposed by Tuckman and Waheed (1981) which was constructed based on the views of Rusell (1974). This method states that the level of mastery or achievement 70 percent is considered good module content and has mastered a high level of achievement.

\section{Result}

Development of Entertainment-Based Teaching and Learning Modules for Numeracy Comprehension Levels for School Children in Hospitals

At the development stage, modules are produced based on the research of essential analysis, theory, literature review' and curriculum review. Information needs analysis is crucial for producing the modules that teachers need. To produce a comprehensive module, the development process takes into account theoretical fusion, literature review and curriculum review. Basically the contents of the module are formatted into two parts namely: (1) introduction and description of the use of the module and (2) there are four stages namely stage 1 : code translation, stage 2: knowledge acquisition, stage 3: analysis, and stage 4: application. Each level has 10 activities. The first part of the module contains a description of the level of numeracy comprehension, this section describes the level that students need to achieve based on the activities carried out.

After following and understanding the first part, the teacher can follow' the activities according to what is instructed in part two, there are four levels and one level there are 10 activities that students need to master and understand so that students can follow or continue to activities in the second stage, then the third stage and fourth. If the student manages to pass all four levels, it shows that

The student has reached the level of numeracy comprehension. The teachers job to guide the learning process and stimulate students to think more creatively and critically. To give a clearer picture of the module, table 1 show the format and division of topics in the module which is divided into two parts

Table 1: The evaluator's approval level to the content of the module analysis.

\begin{tabular}{|l|l|}
\hline Part 1 & Part 2 \\
\hline Introduction & Level 1 \\
\hline Module Purpose & Activity 1: name \\
\hline Module Objectives & Activity 2: Let's Count \\
\hline
\end{tabular}


${ }^{1}$ Siti Rahaimah binti Ali, ${ }^{2}$ Anida binti Sarudin, ${ }^{3}$ Zuria Farhana binti Muhamad

\begin{tabular}{|c|c|}
\hline Part 1 & Part 2 \\
\hline Operating Procedures & Activity 3: select and match \\
\hline Content Module & Activity 4: Gathering Table \\
\hline Level 1 Description & Activity 5: Equal \\
\hline Level 2 Description & Activity 6: Couples \\
\hline Level 3 Description & Activity 7: Fan and take \\
\hline Level 4 Description & Activity 8: listen and round \\
\hline Theories used & Activity 9: Singing sambal counting \\
\hline $\begin{array}{l}\text { Standard Table of Contents of Numbers and Basic } \\
\text { Operations }\end{array}$ & Activity 10 \\
\hline Activities by level & Stage 2 \\
\hline Module implementation period & Activity 1: Name \\
\hline Activity Implementation Period & Activity 2: Basic Mathematics 1 \\
\hline Student age environment & Activity 3: Push (remove / remove) \\
\hline Student group size & Activity 4: Add (Fill / Enter) \\
\hline \multirow[t]{28}{*}{ Student assessment } & Activity $5::$ Basic addition \\
\hline & Activity 6: Twins \\
\hline & Activity 7: Calculate Sodoku \\
\hline & Activity 8: I- You- Aju- Response \\
\hline & Activity 9: Unity \\
\hline & Activity 10: Basic minus \\
\hline & Level 3 \\
\hline & Activity 1: Count me!! \\
\hline & Activity 2: Rotate the response \\
\hline & Activity 3: The color of money \\
\hline & Activity 4: shopping \\
\hline & Activity 5: Subtract in mathematical sentences \\
\hline & Activity 6: Mathematical sentences \\
\hline & Activity 7: Bubble Map \\
\hline & Activity 8: Circle map \\
\hline & Activity 9: Bridge map \\
\hline & Activity 10: Throw Thought \\
\hline & Level 4 \\
\hline & Activity 1: Find the Hid den Numbers! \\
\hline & Activity 2: Fractions \\
\hline & Activity 3: buying \\
\hline & Activity 4: Mass \\
\hline & Activity 5: Add Champion \\
\hline & Activity 6: Puzzle Game \\
\hline & Activity 7: Warm Chairs number \\
\hline & Activity 8: Warm seats of measure \\
\hline & Activity 9: Volume Hot Chairs \\
\hline & Activity 10: Yarn Bracelet \\
\hline
\end{tabular}

The completed module was then reviewed by four different field experts. Expert suggestions are collected and scheduled to find similarities of ideas. This method makes it easier for the researcher to identify which suggestions should be emphasized. The result of the expert proposal equation is marked to see the similarity of opinion on a particular section. Expert recommendations are scheduled to be analyzed as in Table 2.

Table 2: Expert Recommendation

\begin{tabular}{|c|c|c|c|c|}
\hline No & Expert Recommendations (P) & Pl & $\mathrm{P} 2$ & $\mathrm{P} 3$ \\
\hline 1. & Diverse game activities & & & \\
\hline 2. & Teaching and learning activities need to be scheduled and formatted & & & \\
\hline 3. & State the type of game used & & & \\
\hline 4. & Reduce learning standards & & & \\
\hline 5. & Use of electronic media in teaching and learning activities & & & \\
\hline
\end{tabular}


6. Implementation time

7. Game activities should be challenging

8. $\quad$ Needs peer guidance in activities

After the module is improved, the module is given to the same four experts to assess the accuracy of the module content to determine the validity of the module content. In addition, the module was also given to 16 teachers to do the same assessment making the total validity assessment of the module content of 20 assessors. From the aspect of module delivery, as many as 70 percent of the evaluators agreed that the presentation of this module is suitable for students in SDH. 50 percent said the content arrangement of the module is easy for students in SDH to follow. From the content aspect, 65 percent of the evaluators think that the activity proposal is appropriate to the level of development of SDH students and the steps of the activity are presented in an orderly manner. Table 3 shows the analysis of the level of evaluation agreement on the content of the module

Table 3: The content of the module validity

\begin{tabular}{|c|c|c|c|c|}
\hline No & Aspects/Element & $\begin{array}{l}\text { Not } \\
\text { Sure }\end{array}$ & Agree & $\begin{array}{l}\text { Extremely } \\
\text { Agree }\end{array}$ \\
\hline \multicolumn{5}{|c|}{ Delivery } \\
\hline 1 & The module headers correspond to the module objectives & & $\begin{array}{c}12 \\
(60 \%)\end{array}$ & $\begin{array}{c}8 \\
(40 \%) \\
\end{array}$ \\
\hline 2 & The text used in this module is clearly conveyed & $\begin{array}{c}1 \\
(5 \%)\end{array}$ & $\begin{array}{c}9 \\
(45 \%)\end{array}$ & $\begin{array}{c}10 \\
(50 \%)\end{array}$ \\
\hline 3 & This module is suitable for preschool teachers & $\begin{array}{c}2 \\
(10 \%)\end{array}$ & $\begin{array}{c}8 \\
(40 \%)\end{array}$ & $\begin{array}{c}10 \\
(50 \%)\end{array}$ \\
\hline 4 & The contents of modules are easy to follow by preschool teachers. & & $\begin{array}{c}11 \\
(55 \%)\end{array}$ & $\begin{array}{c}9 \\
(45 \%)\end{array}$ \\
\hline 5 & The images in the module have relevance to the written text & & $\begin{array}{c}11 \\
(55 \%)\end{array}$ & $\begin{array}{c}9 \\
(45 \%)\end{array}$ \\
\hline 6 & This module is user friendly. & & $\begin{array}{c}10 \\
(50 \%)\end{array}$ & $\begin{array}{c}10 \\
(50 \%)\end{array}$ \\
\hline \multicolumn{5}{|c|}{ Contents of the module } \\
\hline 7. & Extra activities facilitate teachers to conduct teaching planning. & $\begin{array}{c}1 \\
(5 \%) \\
\end{array}$ & $\begin{array}{c}11 \\
(55 \%) \\
\end{array}$ & $\begin{array}{c}8 \\
(40 \%) \\
\end{array}$ \\
\hline 8. & $\begin{array}{l}\text { The arrangement of content backup activities is structured from } \\
\text { easiest to harder }\end{array}$ & $\begin{array}{c}1 \\
(5 \%)\end{array}$ & $\begin{array}{c}14 \\
(70 \%)\end{array}$ & $\begin{array}{c}5 \\
(25 \%)\end{array}$ \\
\hline 9. & The introduction encourage child motivation to keep learning. & & $\begin{array}{c}7 \\
(35 \%)\end{array}$ & $\begin{array}{c}13 \\
(65 \%)\end{array}$ \\
\hline 10. & $\begin{array}{l}\text { Reserve activity seeks to improve teacher knowledge of how to do } \\
\text { teaching. }\end{array}$ & $\begin{array}{c}2 \\
(10 \%)\end{array}$ & $\begin{array}{c}7 \\
(35 \%)\end{array}$ & $\begin{array}{c}11 \\
(55 \%)\end{array}$ \\
\hline 11. & Proposal of activity seeks to improve the teacher's skills for teaching. & & $\begin{array}{c}9 \\
(45 \%)\end{array}$ & $\begin{array}{c}11 \\
(55 \%)\end{array}$ \\
\hline 12. & $\begin{array}{l}\text { Reserves of activity seeks to improve the mastery of Malay language } \\
\text { skills according to requirements. }\end{array}$ & & $\begin{array}{c}8 \\
(40 \%)\end{array}$ & $\begin{array}{c}12 \\
(60 \%)\end{array}$ \\
\hline 13. & $\begin{array}{l}\text { Reserve activities in accordance with the development stage of } \\
\text { preschool children. }\end{array}$ & & $\begin{array}{c}12 \\
(60 \%) \\
\end{array}$ & $\begin{array}{c}8 \\
(40 \%) \\
\end{array}$ \\
\hline 14. & The activity steps are delivered regularly. & $\begin{array}{c}1 \\
(5 \%)\end{array}$ & $\begin{array}{c}10 \\
(50 \%)\end{array}$ & $\begin{array}{c}9 \\
(45 \%)\end{array}$ \\
\hline 15. & The proposed game material is interesting. & & $\begin{array}{c}9 \\
(45 \%)\end{array}$ & $\begin{array}{c}11 \\
(55 \%)\end{array}$ \\
\hline 16. & The period of the activity reserves according to activities conducted. & & $\begin{array}{c}12 \\
(60 \%) \\
\end{array}$ & $\begin{array}{c}8 \\
(40 \%) \\
\end{array}$ \\
\hline 17. & $\begin{array}{l}\text { The student's work sheet seeks to help teachers perform the } \\
\text { enhancement activities with children. }\end{array}$ & & $\begin{array}{c}8 \\
(40 \%) \\
\end{array}$ & $\begin{array}{c}12 \\
(60 \%)\end{array}$ \\
\hline 18. & $\begin{array}{l}\text { The checklist seeks to help teachers perform student assessments } \\
\text { based on what has been taught. }\end{array}$ & & $\begin{array}{c}7 \\
(35 \%) \\
\end{array}$ & $\begin{array}{c}13 \\
(65 \%) \\
\end{array}$ \\
\hline \multicolumn{5}{|c|}{ Use of Language } \\
\hline 19. & The writing style of this module is easy to read. & & $\begin{array}{c}7 \\
(35 \%)\end{array}$ & $\begin{array}{c}13 \\
(65 \%)\end{array}$ \\
\hline
\end{tabular}




\begin{tabular}{|c|l|c|c|c|}
\hline No & Aspects/Element & $\begin{array}{c}\text { Not } \\
\text { Sure }\end{array}$ & $\begin{array}{c}\text { Agree } \\
\text { Extremely } \\
\text { Agree }\end{array}$ \\
\hline 20. & The word used in the module has no spelling error. & & 11 & 9 \\
$(55 \%)$ & $(45 \%)$ \\
\hline 21. & The language used in modules is easy to understand & 1 & 7 & 12 \\
$(5 \%)$ & $(35 \%)$ & $(60 \%)$ \\
\hline 22. & Method of writing this module is suitable for teachers & & 7 & 13 \\
& & & $(35 \%)$ & $(65 \%)$ \\
\hline
\end{tabular}

The results of the calculation of the level of achievement of the validity of the module content by four experts and $16 \mathrm{SDH}$ teachers showed that the percentage value exceeds 70 percent is 90.3 percent. Findings show that this module has good content validity and meets the target of evaluators who are field experts and users of the module. Table 4 shows the validity values of the module content obtained from 20 evaluators

Table 4:The Validity Values of the Module Content Obtained from 20 Evaluators

\begin{tabular}{|c|c|c|}
\hline Evaluator & Percentage (W) & Content :Validity Level \\
\hline 1 & 86 & Good \\
\hline 2 & 97 & Good \\
\hline 3 & 86 & Good \\
\hline 4 & 90 & Good \\
\hline 5 & 81 & Good \\
\hline 6 & $\mathrm{~d} 5$ & Good \\
\hline 7 & 95 & Good \\
\hline 8 & 97 & Good \\
\hline 9 & 100 & Good \\
\hline 10 & 78 & Good \\
\hline 11 & 86 & Good \\
\hline 12 & 90 & Good \\
\hline 13 & 82 & Good \\
\hline 14 & 97 & Good \\
\hline 15 & 84 & Good \\
\hline 16 & 93 & Good \\
\hline 17 & 100 & Good \\
\hline 18 & 97 & Good \\
\hline 19 & $8 d$ & \\
\hline 20 & 96 & \\
\hline Overall Total f(Min) & & \\
\hline & & \\
\hline
\end{tabular}

\section{Discussions}

Tackling technology in today's education system is deem to be necessary as it can enhance learning and facilitate teaching processes. The creation of e-Assessment, a mobile application that is based onNumeracy Understanding Model is the answer to fulfil the needs of Malaysian curriculum. This method is in line with the implementation of School-Based Assessment (PBS) that has been practice widely in all primary and high school schools. The findings showed that the use of M-learning is one of the medium that can be used towards the 21st century learning, where students' achievement can be seen as a result of various approaches and methods of teaching and facilitating as well as in terms of assessment.

\section{Conclusion}

In conclusion, M-learning is a new paradigm that was created in the field of education which is seen as more relevant to the needs of the students and in line with today's technology developments. With the technology advancement, it is possible to change the form of learning methods to create a broad learning community, to connect people in real-time or virtual worlds, to provide the necessary expertise and support lifelong learning (Sharples, 2000). The use of mobile learning indirectly can improve and enhance the teaching and learning process. Based on this innovation, it can create excitement and students are being able to know their level of numeracy understanding that they acquired. The e-Assessment has the potential to be one of the alternative teaching materials in the future to support learning activities as well as becoming one of the information delivery medium. This study also implies the need to improve the method of numerical understanding among pupils in primary schools through e-Assessment applications. 


\section{Limitations and Future Studies}

In this study, the researcher did not focus on the entire students of school in hospital (SDH) programme in relation to the numeracy thinking strategy as a tool to know their level of numeracy comprehension. The findings of this study were limited to six students only. So the result of this study cannot be generalized to represent the entire students of school in hospital programme. The development of thinking strategy needs to be further expanded so that fun learning can be nurtured from an early stage and students will enjoy learning.

\section{Acknowledgement}

Hence, it is concluded that the thinking strategy on understanding numeracy among school in hospital (SDH) was successfully developed and potentially implemented in teaching and facilitating to determine the level of understanding of numeracy.

\section{References}

1. Abdull Sukor Shaari \& A. Kalaidevi. 2012. Kesan Pendekatan Pembelajaran Masteri Terhadap Pencapaian Kemahiran Membaca Bahasa Melayu Murid Pemulihan Sekolah Rendah. Jurnal Pendidikan Bahasa Malaya, 2(2) : 94-105.

2. Abdullah Md Isa (2004). Penguasaan fakta asas darab di kalangan pelajar Tahun Dua. Tesis Sarjana. Fakulti Pendidikan, Universiti Malaya.

3. Agnes, M. (2003). Numeracy in childhood. London: TIMES.

4. Aini Hassan. (2002). Penggunaan Pelbagai Teknik Mendapatkan Data Kualitatif Pengetahuan Guru. In M. Yusoff, Penyelidikan kualitatif: Pengalaman kerja lapangan kajian. Kuala Lumpur: Universiti Malaya.

5. Amin Salleh, Maheran Abu \& Faridah Abu Hassan. (2002). Matematik Sekolah Rendah. Kuala Lumpur: Bahagian Perancangan Dan Penyelidikan, Kementerian Pelajaran Malaysia.

6. Anderson, J. (2014). Forging New Opportunities for Problem Solving in Australian Mathematics Classrooms Through the First National Mathematics Curriculum. In Yeping, L. \& Glenda, L. (Eds.), Mathematics Curriculum in School Education, Dordrecht: Springer.

7. Anghileri, J. (2000). Intuitive Approaches, Mental Strategies and Standard Algorithms. In Anghileri (Ed). Principles and practices in arithmetic's teaching. Buckingham: Open University Press.

8. Askew, M. B. (2007). Effective teachers of numeracy. London School of Educational.

9. B.Bussi, G. A. Jones, R. A. lesh \& D. Tirosh (eds),. Handbook of International Research Mathematics Education, 432-487.

10. Bahagian Pembangunan Kurikulum (2010). Programme Literacy and Numeracy Screening (LINUS). Kuala Lumpur: Pusat Perkembangan Kurikulum.

11. Bahagian Pembangunan Kurikulum, (2010). Bahagian Sekolah Rendah. Program Literasi dan Numerasi (Linus). Kementerian Pelajaran Malaysia

12. Ball, D. (2002). Mathematical proficiency for all students: Toward a strategic research and development program in mathematics education. RAND Education/Science and Technology Policy Institute.

13. Bobies, J. C. (2005). Supporting teachers in the development of young children's mathematical thinking: Three Large scale cases. Mathematics Education Research Journal 16(3), 27-57.

14. Brown, M. A. (2003). The key role of educational research in the development and evaluation of the National Numeracy Strategy. British Educational Research Journal 29(5), 663-680.

15. Buletin Yayasan Nurul Yaqeen. 2012. Sekolah Dalam Hospital Diinstitusikan.

16. Clarke, D (2004). Mathematics teaching in Grades K-2: Painting a picture of challenging, supportive and effective classrooms. In R.N Rubenstien \& G.W Bright (Eds). Perspectives on the teaching of mathematics (66th Yearbook of the National Council of Teachers of Mathematics. Reston,VA:NCTM.

17. Creswell, J. W. (2007). Qualitative Inquiry \& Research Design Ed. ke-2. London: Sage publication.

18. Dave Baker, A. T. (2010). Navigating Numeracies home/school numeracy practices. London: King College.

19. Department of skill (2011). Literacy and Numeracy. Dublin: Department of Education and Skill.

20. Dowker,A. (2005). Early identification and intervention for students with mathematics difficulties. Journal of Learing Disabilities, 38, 4, 324-332.

21. Earle, L. W. (2003). Watching and Learning 3. Final report of the External Evaluation of England's National Literacy and Numeracy Strategies. Toronto: Ontario Institute for Studies in Education University of Toronto.

22. Gal, I. (2002). Adult Numeracy Development: theory, research, practice. Hampton press.

23. Ginsburg, L. (2000). Instructional strategies for adult numeracy education. Adult numeracy development: Theory, research. practice, $89-114$. 
24. Ginsburg, L. Manly, M., \& Schmitt, M.J (2006). The component of numeracy. Cambridge, MA: National Center for the Study of Adult Leaning and Literacy

25. Junaidah Mohamed Kassim \& Rasyidah Haji Anuar (2006). Pembangunan Model PeKA Bagi Perisian Kursus E-Pembelajaran Animasi 3D Menggunakan Pendekatan Masteri. Fakulti Teknologi dan Sains Maklumat : Universiti Kebangsaan Malaysia.

26. Kamus Dewan. 2000.Dewan Bahasa dan Pustaka. Kuala Lumpur

27. Kementerian Pelajaran Malaysia (2009). Huraian Sukatan Pelajaran Matematik Tahun 4. Kuala Lumpur: Pusat Perkembangan Kurikulum.

28. Kementerian Pelajaran Malaysia (2010). Bengkel Kajian Semula Pelan Induk Pembangunan Pendidikan . Teks Ucapan

29. Kilpatrick, J. S. (2001). All adding it up: Helping children learnmathematics. Whingston Dc: Nasional Academic Press.

30. Lembaga Peperiksaan Malaysia (2011). Analisa prestasi dan gred purata matematik. Kuala Lumpur: Lembaga Peperikasaan Malaysia.

31. Luke \& Freebody. (2008). A map of possible practise: futher notes on the four resource model practically primary. Journal Research Mathematics Education, 4(2), 5-8.

32. Luke \& Freebody (2009). Critical numeracy. Numeracy in the news, Faculty of Education, University of Tasmania.

33. Martin and D. Schiffer. A Research Companion to Principles and Standards for School Mathematics, 6898.

34. Matthijsse, W. (2000). Adult Numeracy at The Elementary Level: Addition and Subtraction Up to 100. In G. Iddo, Adult Numeracy Development: Theory, Research, Practice (pp. 133-155). UK.

35. NCTM. (2000). Principles and standard for school mathematics. USA: Reston, Va Author.

36. New South Wales Department of Education and Training (2001). Count me in too professional development package. Ryde: NSW Department of Education and Training.

37. Noraini Idris (2011). Kesedaran Metakognisi Dan Pemahaman Konsep Dalam Penyelesaian Masalah Matematik. National Academic conference.

38. Noraini Idris, (2004). Mathematics learning in English as a second language. Diges Pendidik, 4(1), 64-72.

39. Noraini Idris, (2000). Linguistic aspects of mathematical education: How precise do teachers need to be? In Cultural and Language Aspects of Science, Mathematics and Technical Education. Universiti Brunei Darussalam

40. Ornstein, A. C. \& Hunskin, F. P. 2004. Curriculum: Foundation principles and issues.

41. Patton, M. (2002). Qualitative evaluation and research methods. Ed. ke-3. Thousand Oaks, CA: Sage Publishing.

42. Penny, M. (2005). Explanations of mathematical concepts in Japanese, Chinese, and U>S first and fifthgrade classrooms. Cognition and Instruction, 18, 181-207.

43. Peters, E., \& Castel, A. (2009). Numerical representation, math skills, memory, and decision-making [Peer commentary on the paper "Numerical representation in the parietal lobes: Abstract or not abstract?" by R. C. Kadosh \& V. Walsh]. Behavioral and Brain Sciences, 32, 347-348.

44. Portal Rasmi Hospital Serdang. Sekolah Dalam Hospital. http://hserdang.moh.gov.my/

45. Portal Rasmi Suruhanjaya Perkhidmatan Pelajaran Malaysia. Pembantu Pengurusan Murid. http://www.spp.gov.my/

46. Pusat Perkembangan Kurikulum. (2010). Programme literacy and numeracy screening (LINUS). Kuala Lumpur: Bahagian Pembangunan Kurikulum, Pusat Perkembangan Kurikulum.

47. Rabi'Atul 'Adawiyah Ismail. 16 Julai 2011. Teruja Belajar Sambil Dirawat. Harian

48. Sabri Ahmad. (2006). Isu-isu dalam pendidikan matematik. Utusan publication distributer sdn. Bhd.

49. Schoenfeld Allan.H (2002). Research method in (Mathematics) education. Dlm L.D. English, M.

50. Sinar Harian. 3 Oktober 2013. PPPM Selari Matlamat Pendidikan UNESCO.

51. Siti Rahaimah \& Noraini Idris (2014). Numerasi sekolah rendah. UPSI

52. Siti Rahaimah \& Noraini Idris. (2013). A model to identify the level of numeracy understanding of primary school pupils: A case study. International Journal of Computer Application (0975-8887) (Journal Electronic) Vol. 67 no.5, April 2013.

53. Siti Rahaimah \& Noraini Idris. (2013). A model to identify the level of numeracy understanding of primary school pupils: a case study. Jurnal Pendidikan Sains \& Matematik Malaysia. Vol.3. No.2 Dis. 2013. pp. 24-42.

54. Siti Rahaimah Ali \& Noraini Idris (2014). Numerasi sekolah rendah. Perak: Universiti Pendidikan Sultan Idris.

55. Siti Rahaimah Ali \& Noraini Idris. (2013) A model to identify the level of numeracy understanding of primary school pupils: A case study. International Journal of Computer Application (0975-8887) (Journal Electronic) 67(5) 
56. Siti Rahaimah Ali \& Noraini Idris. (2013) A Model to Identify the Level of Numeracy Understanding of Primary School Pupils: A Case Study. Jurnal Pendidikan Sains \& Matematik Malaysia,3(2), 24-42.

57. Skemp. (1978). Relational understandiang and instrumental understanding. The Arithmetic Teacher 26(3), 9-15. Noraini Idris (2009). Penyelesaian Masalah Daya Penggerak Dalam Pengajaran Dan Pembelajaran. Persidangan Kebangsaan Pendidikan Matematik. Sungai Petani: Institut Pendidikan Guru Malaysia.

58. Star, J.R (2005). Conceptualizing procedural knowledge. Journal for Research in Mathematics Education, 36(5), 404-411.

59. Syed Ismail Syed Mustafa. 2010. Asas Kepimpinan \& Perkembangan Profesional. Penerbitan Multimedia Sdn.Bhd.Selangor.

60. USA: Pearson Education

61. Warisan Biduanda. 